\title{
A simple and rapid immunochromatographic test strip for detection of white spot syndrome virus (WSSV) of shrimp
}

\author{
Weerawan Sithigorngul ${ }^{1}$, Sombat Rukpratanporn ${ }^{2}$, Nilawan Pecharaburanin ${ }^{3}$, \\ Siwaporn Longyant ${ }^{1}$, Parin Chaivisuthangkura ${ }^{1}$, Paisarn Sithigorngul ${ }^{1, *}$
}

\author{
${ }^{1}$ Department of Biology, Faculty of Science, Srinakharinwirot University, Sukhumvit 23, Bangkok 10110, Thailand \\ ${ }^{2}$ Center of Excellence for Marine Biotechnology at Chulalongkorn University, National Center for Genetic Engineering \\ and Biotechnology (BIOTEC), Bangkok 10330, Thailand \\ ${ }^{3}$ Pacific Biotech, Petchaboon 67000, Thailand
}

\begin{abstract}
A simple strip-test kit for white spot syndrome virus (WSSV) detection was developed using monoclonal antibody W29 (against the VP28 structural protein) conjugated with colloidal gold as the detector antibody. A rabbit anti-recombinant VP28F118 (rVP28) protein antibody in combination with a W28 monoclonal antibody was used as the capture complex at the test line (T), and goat anti-mouse IgG antibody (GAM) was used as the capture antibody at the control line (C). For evidence, the ready-to-use strip was kept in a plastic case and stored in a desiccated plastic bag. A sample volume of $100 \mu \mathrm{l}$ gill homogenate in application buffer was applied to the sample chamber at one end of the strip and allowed to flow by chromatography through the nitrocellulose membrane to the other end. In test samples containing WSSV, the virus bound to the monoclonal antibody conjugated with colloidal gold and the resulting complex was captured by the antibodies at $\mathrm{T}$ to give a reddishpurple band. Any unbound monoclonal antibody conjugated with colloidal gold moved across $\mathrm{T}$ to be captured by the GAM and formed a band at C. In samples without WSSV or with WSSV below the limit of detection of the kit, only the band at $\mathrm{C}$ was seen. This method was 4 times less sensitive than dot blotting, and about 2000000 times less sensitive than 1-step PCR. Nonetheless, it could be used to screen individual shrimp or pooled shrimp samples to confirm high levels of WSSV infection or WSSV disease outbreaks. The beneficial features of this kit are that simple, convenient and quick results can be obtained without the requirement of sophisticated tools or special skills.
\end{abstract}

KEY WORDS: Colloidal gold $\cdot$ Monoclonal antibody $\cdot$ Polyclonal antibody $\cdot$ Penaeus monodon $\cdot$ White spot syndrome virus $\cdot$ WSSV

Resale or republication not permitted without written consent of the publisher

\section{INTRODUCTION}

White spot syndrome virus (WSSV) is a highly infectious agent that causes mass mortality in farmed penaeid shrimp worldwide (Lightner \& Redman 1998). Recently, immunological-based diagnostic methods were developed for detection of WSSV, and a polyclonal antibody and monoclonal antibodies against purified WSSV or its recombinant VP28 structural protein produced. They have been used for detection of
WSSV in various assays such as dot blotting, Western blotting, immunohistochemistry and antigen-captured ELISA (Nadala et al. 1997, 1998, 2000, 2002, Poulos et al. 2001, Anil et al. 2002, Lui et al. 2002, Chaivisuthangkura et al. 2004). Recently, a dotimmunogold filtration assay (DIGFA) using a monoclonal antibody colloidal gold conjugate was developed for the direct detection of WSSV fixed on the nitrocellulose membrane (Wang et al. 2006). However, these techniques could be performed only in the labo- 
ratory by well-trained personnel. A further improvement in the form of an immunochromatographic test was also developed (Wang \& Zhan 2006); however, the stability of the test strip was relatively shorter (stable for approximately $1 \mathrm{yr}$ at $4^{\circ} \mathrm{C}$ ) than that of an available commercial test strip (Shrimple) from the EnBio shrimp Virus Detection Kit Series. The purpose of the present study was to use the available monoclonal antibodies and the polyclonal antibody for preliminary development of a simple immunochromatographic test strip that could be used in the field by untrained personnel.

\section{MATERIALS AND METHODS}

Specimens. Penaeus monodon (15 to $20 \mathrm{~g}$ ) purchased from a farm near Bangkok were maintained in 10 ppt diluted seawater. Macrobrachium rosenbergii (15 to $30 \mathrm{~g}$ ) purchased from the Ayuthaya Shrimp Market were maintained in freshwater. Haemolymph was collected from both species to serve as negative control samples and as the diluent for sensitivity tests. The haemolymph from both species was confirmed negative for WSSV by PCR as previously described (Chaivisuthangkura et al. 2004).

Preparation of WSSV. Haemolymph from WSSVinfected Penaeus monodon was filtered through a $0.45 \mu \mathrm{m}$ membrane and diluted to 1:50 with $2 \mathrm{X}$ sterile phosphate-buffered saline (PBS) (2X PBS =0.3 M PBS). The diluted haemolymph was injected into $P$. monodon at approximately $2 \mathrm{\mu l} \mathrm{g}^{-1}$ body weight. One or $2 \mathrm{~d}$ after injection, shrimp that showed slow movement were selected and haemolymph collected, which was then mixed with an anticoagulant (Rodriguez et al. 1995) at a ratio of 1:1. The haemolymph from each shrimp was tested for WSSV by dot blotting using the monoclonal antibody W29 as described previously (Sithigorngul et al. 2002). WSSV-infected shrimps and pooled positive haemolymph samples were stored at $-20^{\circ} \mathrm{C}$ until use.

Preparation of W29 and W28 monoclonal antibodies. W29 and W28 hybridomas (Chaivisuthangkura et al. 2004) were grown in serum-free media 'Hybridoma-SFM' (Gibco). The conditioned medium was collected and purified for W29 and W28 antibodies using Protein A agarose columns (Roche) as described in the manufacturer's instructions. The antibody was dialyzed against phosphate buffer ( $\mathrm{PB} 10 \mathrm{mM}, \mathrm{pH}$ 7.3) and adjusted to a concentration of $1 \mathrm{mg} \mathrm{ml}^{-1}$.

Preparation of polyclonal antibody specific to rVP28F118 protein. Recombinant VP28F118 structural protein was prepared by sodium dodecyl sulphate polyacrylamide gel electrophoresis (SDS-PAGE) as described previously (Chaivisuthangkura et al. 2004), and was used for intra-peritoneal immunization of 3 New Zealand white rabbits $\left(0.5 \mathrm{mg} \mathrm{rabbit}^{-1}\right)$. Rabbits were subsequently boosted 3 more times. One week after the third booster injection, rabbit antisera were collected and pre-absorbed with Escherichia coli M15 (pREP4) overnight. Each antiserum was tested against E. coli lysate, purified rVP28F118 protein and haemolymph from WSSV-infected Penaeus monodon by Western blotting, and also against head tissues from WSSV-infected P. monodon by immunohistochemistry as described by Sithigorngul et al. (2002). The high titer and specific antisera were pooled and purified using Protein A agarose columns (Roche) according to the manufacturer's instructions, and the resulting preparation was designated as anti-rVP28 polyclonal antibody. The antibody was dialyzed against $\mathrm{PB}$ and its protein content was determined and adjusted to a concentration of $1 \mathrm{mg} \mathrm{ml}^{-1}$.

Preparation of immunochromatographic test strips. Test strips were prepared by Pacific Biotech. The W29 antibody was conjugated to colloidal gold (diameter = $10 \mathrm{~nm}$ ) and sprayed onto a glass fiber pad at 1 and $1.5 \mu \mathrm{cm}^{-1}$. A combination of rabbit anti-rVP28F118 antibody $\left(1 \mathrm{mg} \mathrm{ml}^{-1}\right)$ and W28 antibody $\left(1 \mathrm{mg} \mathrm{ml}^{-1}\right)$ at ratio of 4:1 was micro-sprayed onto a nitrocellulose membrane at 1 and $1.5 \mu \mathrm{cm}^{-1}$ at a position that would become the capture test line $(\mathrm{T})$ of the completed strip. Goat anti-mouse IgG antibody (GAM) in PB (1 mg $\mathrm{ml}^{-1}$ ) was micro-sprayed onto the same nitrocellulose strip at a position that would become the capture control line (C) at 1 and $1.5 \mu \mathrm{cm}^{-1}$. The membrane was dried at $40^{\circ} \mathrm{C}$ overnight. For kit assembly, the nitrocellulose membrane was cut into $3.5 \mathrm{~mm}$-wide strips and assembled with W29 conjugated with colloidal gold at one end upstream of $\mathrm{T}$, and an absorption pad at the opposite end downstream from C (Fig. 1). Each completed assembly was housed in a plastic case and stored in a desiccated plastic bag.

Specificity testing. Gill filaments from WSSVinfected Penaeus monodon and from uninfected $P$. monodon were individually homogenized in $100 \mu \mathrm{l}$ application buffer (30 mM Tris, $336 \mathrm{mM} \mathrm{NaCl}, 9 \mathrm{mM}$ EDTA, $1 \%$ Triton X-100, pH 9.3), and the supernatant solutions were applied to the sample well of individual test strips so that they would flow chromatographically along the nitrocellulose strip past $\mathrm{T}$ and $\mathrm{C}$ before entering the absorption pad. The test result could be observed within 15 min after sample application. A positive result consisted of the appearance of a reddish-purple band at both $\mathrm{T}$ and $\mathrm{C}$, whereas a negative result consisted of a reddish-purple band at $\mathrm{C}$ only (Fig. 2). Similar tests were performed using haemolymph mixed with application buffer at a ratio of $1: 1$ before application to the strip. To determine test specificity, samples from shrimp infected with yellow head virus (YHV) and Taura syndrome virus (TSV) were also tested. 


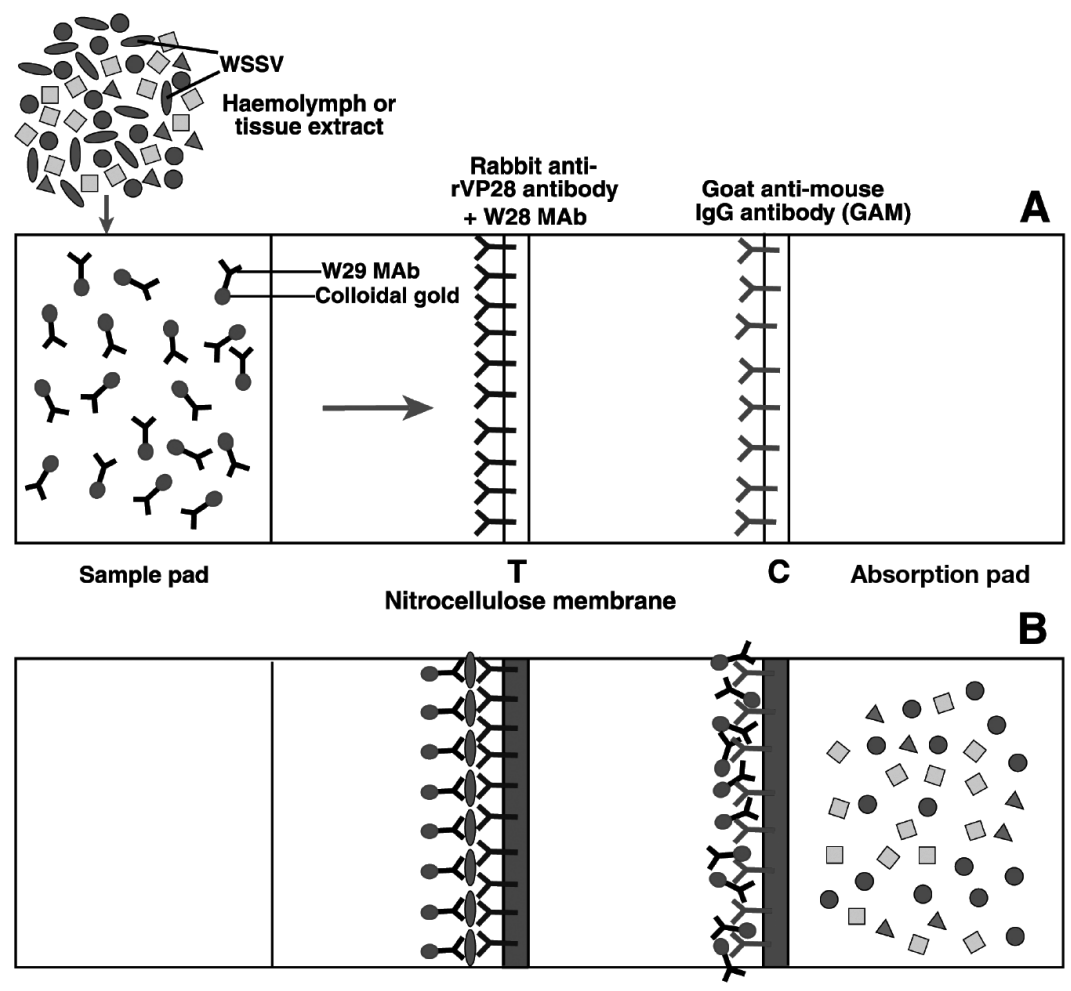

Fig. 1. Test strip diagram. (A) Positions of various antibodies on test strip. (B) After application of sample containing WSSV to the sample pad, the conjugated antibody and antigen complex is captured by antibodies on the test line (T), giving a reddish-purple band of colloidal gold, and the unbound conjugated antibody moves across the test line and is captured by goat anti-mouse IgG antibody (GAM) to form a band at the control line (C). The remainder of the sample accumulates on the absorption pad. MAb: monoclonal antibody nucleic acid extraction kit (Roche Molecular Biochemicals) and tested by PCR using primers VP28F (5'-CCGGATCCATGGATGGGATCTTTC TTTCACC TTTCG-3') and VP28R (5'-TGCACT GCAGTTACTCGGTCTCAG TGCCA G3') to yield an amplicon of $633 \mathrm{bp}$ (Chaivisuthangkura et al. 2004). These samples were also used for 3 test strips and for dot blotting as described above. The last dilution that yielded an observable positive result was compared among the test methods. Similar tests were carried out using haemolymph from WSSV-infected $P$. monodon diluted with haemolymph from uninfected $M$. rosenbergii. The commercially available WSSV test strip (Shrimple) was also tested to compare sensitivity using the same protocol.

Thermostability testing. Immunochromatographic test strips in desiccated plastic bags were stored in a $60^{\circ} \mathrm{C}$ oven for $0,10,20$ and $30 \mathrm{~d}$ before testing against gill extracts from WSSVinfected Penaeus monodon at 1:10 an 1:50 dilutions (5 strips for each treatment). The immunoreactive bands were compared with the results from gill extracts of uninfected $P$. monodon.

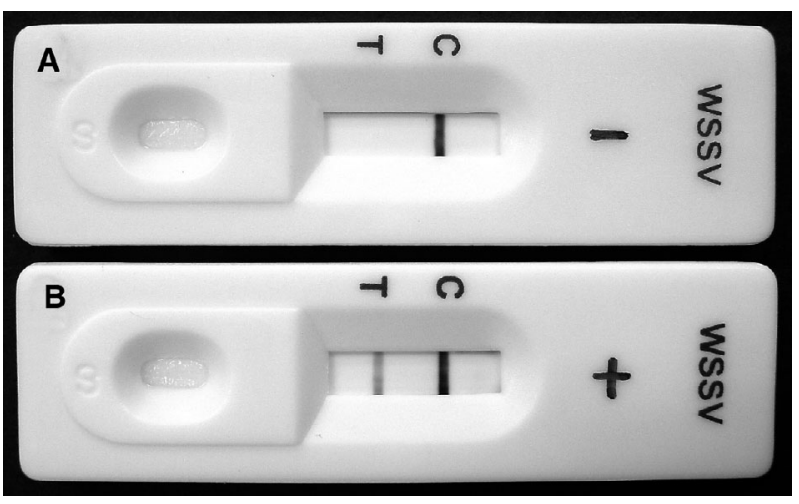

Fig. 2. Test strip. Gill homogenates from (A) uninfected and (B) WSSV-infected Penaeus monodon applied to the test strip. $\mathrm{T}$ : test line; $\mathrm{C}$ : control line

Sensitivity testing. Supernatant solution from a gill homogenate of WSSV-infected Penaeus monodon was serially diluted with gill extract from Macrobrachium rosenbergii that were confirmed negative for WSSV by subsequent PCR testing. Nucleic acid from $200 \mu \mathrm{l}$ of each stock solution and diluted sample was prepared using a

\section{RESULTS AND DISCUSSION}

\section{Test strip optimization}

After pre-absorption with Escherichia coli, all rabbit antisera produced by immunization with rVP28F118 protein showed high specificity for both the recombinant protein and for the natural protein of WSSV as determined by Western blotting. Results were similar to those obtained using the W29 monoclonal antibody (MAb). The antisera did not cross-react with shrimp tissues (Fig. 3). The sensitivity of the antisera tested by dot blot assay was about 4 times lower than that of W29 MAb (Fig. 4). All antisera were pooled and purified through a Protein A column for test strip production. W29 MAb conjugated with colloidal gold sprayed at $1.5 \mu \mathrm{cm}^{-1}$ on the sample pad, and combined rabbit anti-rVP28 antibody and W28 MAb (4:1) sprayed at $1.5 \mu \mathrm{cm}^{-1}$ at $\mathrm{T}$ gave the best assay result, yielding the strongest band and giving the highest sensitivity of detection without showing false positive results at $\mathrm{T}$ with haemolymph from uninfected Penaeus monodon or Macrobrachium rosenbergii or from YHV- or TSV- 


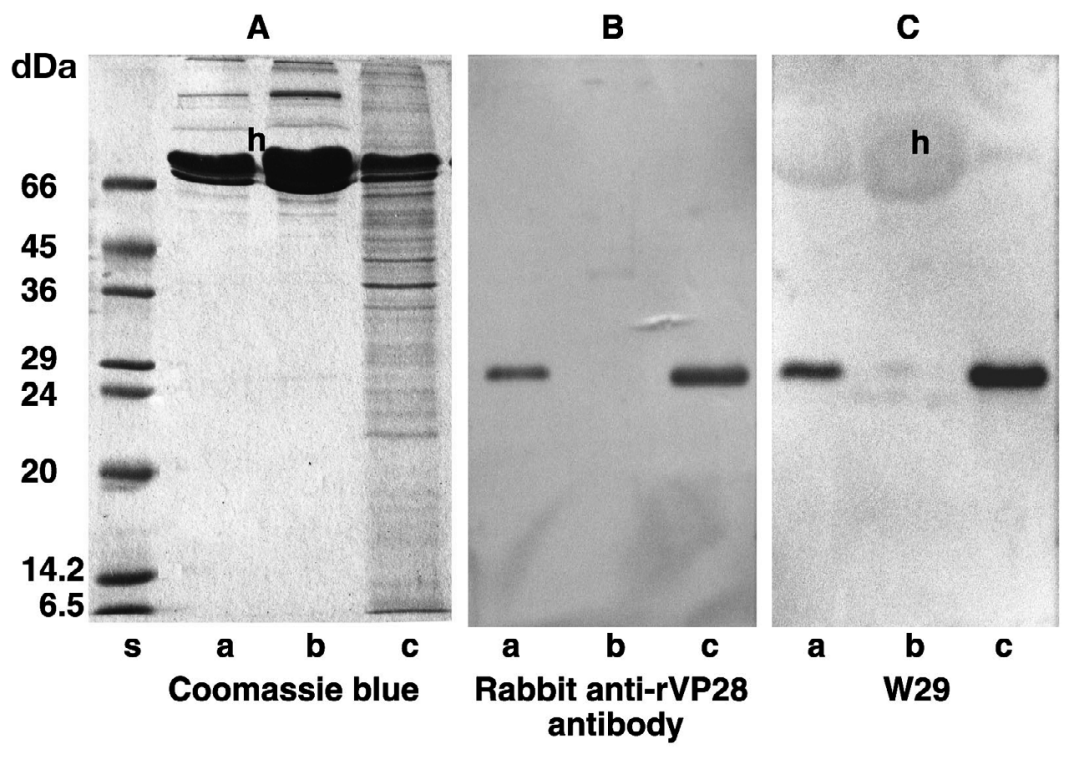

Fig. 3. SDS-PAGE and Western blot analysis. (A) Haemolymph from WSSVinfected (a) and uninfected (b) Penaeus monodon and gill extract from WSSVinfected P. monodon (c) were electrophoresed and stained with Coomassie blue. s: standard proteins; h: haemocyanin. Other parts of the gel were electroblotted to a nitrocellulose membrane and probed with (B) rabbit polyclonal antibody against rVP28F118 protein or (C) W29 monoclonal antibody (MAb). Numbers on the left are molecular masses of standard marker proteins

infected shrimps. Only $2 \mathrm{mg}$ of W29 MAb, $0.5 \mathrm{mg}$ of W28 MAb and $2 \mathrm{mg}$ of rabbit anti-rVP28 antibody would be required to produce over 2000 kits.

\section{Test strip sensitivity}

The lowest ratio of WSSV-infected gill extract of Penaeus monodon diluted with uninfected gill extract of $P$. monodon that gave an unambiguous positive teststrip result was 1:50. This was less sensitive than the dot blot method (dilution ratio 1:200) with W29 MAb. However, the test strip is much more convenient because no additional equipment is required and the result can be obtained very quickly. In contrast, the dot blot assay required at least $7 \mathrm{~h}$ after application of the sample to the membrane to obtain a result.

By PCR, the same sample of haemolymph at a dilution ratio of 1:100 000000 produced a lightly detectable band (Fig. 5). Therefore, the WSSV test strip was about 2000000 times less sensitive than 1-step PCR. The sensitivity of both the WSSV test strip and the commercially available Shrimple test strip was similar.

\section{Test strip stability}

Thermal stability testing at $60^{\circ} \mathrm{C}$ using gill extracts at a dilution ratio of 1:10 revealed no differences in intensity of immunoreactive bands after 0,10 and $20 \mathrm{~d}$ incubation. Intensity after a $30 \mathrm{~d}$ incubation period was reduced. However, when gill extract was used at a dilution ratio of 1:50, no differences in the intensity of the immunoreactive bands were observed among treatments. These results indicated that the strip remained functional under storage conditions equivalent to approximately $2 \mathrm{yr}$ at room temperature (Paek et al. 2000).

\section{Sample source comparisons}

In place of gill extracts, 1 walking leg or 1 swimmeret from a juvenile (10 to 20 g) WSSV-infected Penaeus monodon was ground into $100 \mu \mathrm{l}$ of application buffer, or haemolymph was mixed with an application buffer at a ratio of 1:1. These samples produced similar results to those obtained using gill extracts (Fig. 1) but with a lower dilution ratio factor (1:20 limited detection), despite the fact that gills are considered to be one of the best sample sources because they contain a large amount of epithelial tissue, a major target of WSSV. In summary, this kit is convenient for rapid detection of WSSV infection in shrimp and tests can be performed rapidly by unskilled personnel at the farm site.

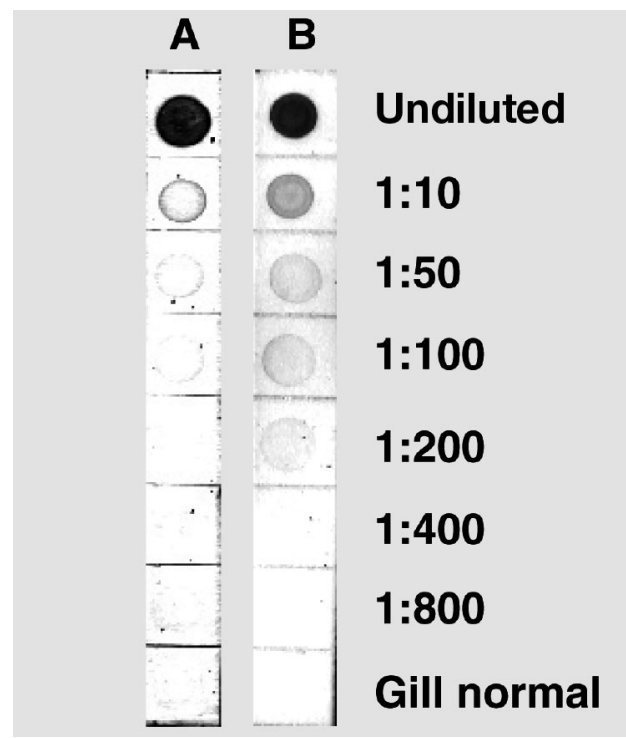

Fig. 4. Dot blotting assay. Detection limit of (A) rabbit antirVP28 antibody and (B) W29 antibody with a serially diluted gill extract from WSSV-infected (dilution ratio 1:10 to 1:800) and uninfected ('Gill normal') Penaeus monodon 


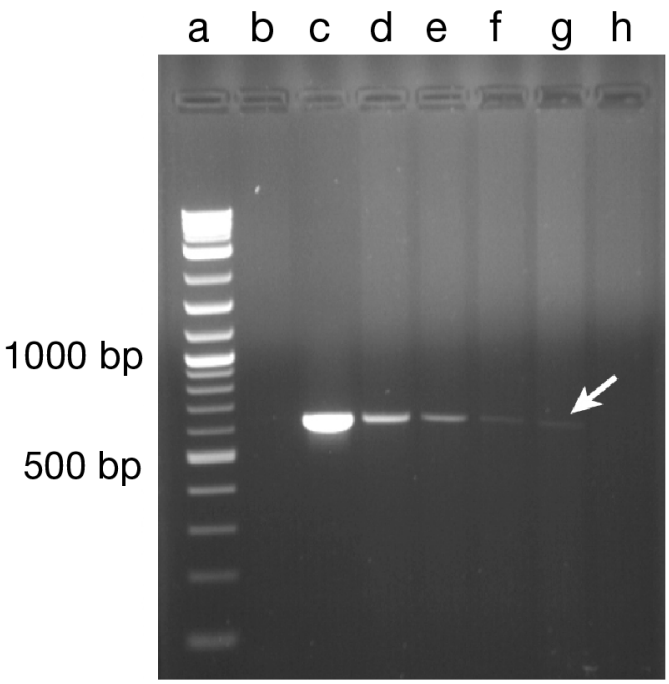

Fig. 5. PCR of gill extract from WSSV-infected Penaeus monodon. Lane a: DNA marker, b: uninfected gill extract, c: undiluted gill extract from WSSV-infected P. monodon. Lanes d-h are serially diluted with uninfected gill extract from Macrobrachium rosenbergii. Lane d: $1: 1 \times 10^{-5}$, e: $1: 1 \times 10^{-6}$, f: $1: 1 \times$ $10^{-7}, \mathrm{~g}: 1: 1 \times 10^{-8}, \mathrm{~h}: 1: 1 \times 10^{-9}$. Arrow: $633 \mathrm{bp}$ PCR product

\section{Comparison to other methods}

Another simple immuno-based assay developed for detection of WSSV infection in shrimp is reverse passive latex agglutination, which uses high density latex beads conjugated to a polyclonal antibody preparation. This requires an incubation time of over $4 \mathrm{~h}(\mathrm{Oku}-$ mura et al. 2004). In a DIGFA, MAbs conjugated with colloidal gold were used for direct detection of WSSV in samples spotted on nitrocellulose membranes (Wang et al. 2006). However, background staining of the negative control samples was high, and it was difficult to differentiate background staining from low infection samples. Although the sensitivity of these tests cannot be compared with that of the test strip described herein due to differences in samples used for testing, it is possible that they may be more sensitive. Despite this, the test strip has several advantages such as simplicity, rapidity, and ease of use without prior preparation of equipment. These are particularly advantageous features for disease outbreak confirmation at shrimp farms. By allowing rapid and early confirmation as to whether or not a WSSV disease outbreak is imminent, real-time management decisions regarding emergency harvests would be possible. Another immunochromatographic test kit for detection of WSSV (Wang \& Zhan et al. 2006) differed from the test strip developed in the present study in several aspects. Firstly, the captured antibodies consisted of 2 MAbs. Secondly, a round dot of captured MAbs was used instead of a narrow line. Thirdly, there was no control line with GAM; and fourthly, the stability of the strip in storage was about 1 yr at $4^{\circ} \mathrm{C}$. However, the sensitivity of both test strips could not be compared owing to differences in sample preparation and the diluents used to dilute the sample. It may be possible to further improve the sensitivity of the test by adding high-affinity antibodies against other major WSSV structural proteins such as VP26 and VP19.

It is generally recognized that lateral-flow test strips are less sensitive than ELISA (Lui et al. 2002) for detection of WSSV. In addition, a recent publication on a lateral-flow test strip similar to ours (Powell et al. 2006) indicated that many samples lightly infected with WSSV produced negative test results with the strip but positive test results by PCR. Thus, we suggest that our test strip and other similar strips would be most suitable for pond-site confirmation of heavy WSSV infections such as would be present in moribund shrimp just prior to and during full-blown WSSV outbreaks. Such confirmation is necessary because all gross signs of WSSV infection are unreliable and must be backed up by histological, immunological, or molecular tests (Flegel et al. 1997). The strips are not recommended for screening of lightly infected broodstock, postlarvae used to stock shrimp ponds, or other potential carriers of WSSV.

Acknowledgements. The present study was supported by the National Center for Genetic Engineering and Biotechnology (BIOTEC), Thailand.

\section{LITERATURE CITED}

Anil TM, Shankar KM, Mohan CV (2002) Monoclonal antibodies developed for sensitive detection and comparison of white spot syndrome virus isolates in India. Dis Aquat Org 51:67-75

Chaivisuthangkura P, Tangkhabuanbutra J, Longyant S, Sithigorngul W, Rukpratanporn S, Menasveta P, Sithigorngul P (2004) Monoclonal antibodies against a truncated viral envelope protein (VP28) can detect white spot syndrome virus (WSSV) infections in shrimp. ScienceAsia 30:359-363

Flegel TW, Boonyaratpalin S, Withyachumnarnkul B (1997) Progress in research on yellow-head virus and white-spot virus in Thailand. In: Flegel TW, MacRae IH (eds) Diseases in Asian aquaculture III. Asian Fisheries Society, Manila, p 285-295

Lightner DV, Redman RM (1998) Shrimp disease and current diagnosis methods. Aquaculture 164:201-220

Lui W, Wang YT, Tian DS, Yin ZC, Kwang J (2002) Production of monoclonal antibodies (MAbs) specific to an envelope protein $(28 \mathrm{kDa})$ of white spot syndrome virus (WSSV) of shrimp and detection of WSSV by MAb-based antigencapture enzyme-linked immunosorbent assay. Dis Aquat Org 49:11-18

Nadala ECB, Loh PC (2000) Dot-blot nitrocellulose enzyme immunoassays for the detection of white-spot virus and yellow-head virus of penaeid shrimp. J Virol Methods 84:175-179 
Nadala ECB, Tapay LM, Loh PC (1997) Yellow-head virus: a rhabdovirus-like pathogen of penaeid shrimp. Dis Aquat Org 31:141-146

Nadala ECB, Tapay LM, Loh PC (1998) Characterization of non-occluded baculovirus-like agent pathogenic to penaeid shrimp. Dis Aquat Org 33:221-229

Nadala ECB, You Z, Loh PC (2002) Detection of shrimp viral pathogens with a simple dot-blot enzyme immunoassay protocol. In: Lavilla-Pitago CR, Cruz-Laceirda ER (eds) Diseases in Asian aquaculture IV. Asian Fisheries Society, Manila, p 37-44

Okumura T, Nagai F, Yamamoto S, Yamano $\mathrm{K}$, Oseko N, Inouye K, Oomura H, Sawada H (2004) Detection of white spot syndrome virus from stomach tissue homogenate of the kuruma shrimp (Penaeus japonicus) by reverse passive latex agglutination. J Virol Methods 119:11-16

Paek SH, Lee SH, Cho JH, Kim YS (2000) Development of rapid one-step immunochromatographic assay. Methods 22:53-60

Poulos BT, Pantoja CR, Bradley-Dunlop D, Aguilar J, Lightner DV (2001) Development and application of mo-

Editorial responsibility: Timothy Flegel, Bangkok, Thailand noclonal antibodies for the detection of white spot syndrome virus of penaeid shrimp. Dis Aquat Org 47: $13-23$

Powell JWB, Burge EJ, Browdy CL, Shepard E (2006) Efficiency and sensitivity determination of Shrimple ${ }^{\circledR}$, an immunochromatographic assay for white spot syndrome virus (WSSV), using quantitative realtime PCR. Aquaculture 257:167-172

Rodriguez J, Boulov V, Mialhe E, Bachere E (1995) Characterization of shrimp haemocytes and plasma component by antibodies. J Cell Sci 108:1043-50

Sithigorngul $\mathrm{P}$, Rukpratanporn S, Longyant S, Chaivisuthangkura P, Sithigorngul W, Menasveta P (2002) Monoclonal antibodies specific to yellow-head virus (YHV) of Penaeus monodon. Dis Aquat Org 49:71-76

Wang Z, Zhan W (2006) Development of an immunochromatographic test to detect white spot syndrome virus of shrimp. Aquaculture 255:196-200

Wang X, Zhan W, Xing J (2006) Development of dot-immunogold filtration assay to detect white spot syndrome virus of shrimp. J Virol Methods 132:212-215

Submitted: April 24, 2006; Accepted: July 15, 2006 Proofs received from author(s): September 19, 2006 